\title{
Georges Frédéric Parrot and the Imperial St. Petersburg Academy of Sciences ${ }^{1}$
}

\author{
Ekaterina Basargina \\ St. Petersburg Branch of the \\ Archive of Russian Academy of Sciences \\ Universitetskaya nab. 1, \\ St. Petersburg 196158, Russia \\ E-mail: spbaran-publications@yandex.ru
}

Abstract: In 1826, the president of the Imperial St. Petersburg Academy of Sciences Sergey Uvarov was happy to succeed in having a prominent scientist and public figure at the Academy. It was Georges Frédéric Parrot (1767-1852), a protagonist of the Enlightenment ideology, a "personal friend" of Alexander I's, an emeritus professor and the first Rector of the Dorpat University, who was elected at the very beginning of the reign of Nicholas I, on the eve of the centenary of the Academy. Parrot gave nearly 15 years to the Academy of Sciences. Throughout it all, he was a kind of Uvarov's agent at the University of Dorpat, the one capable not only of estimating the extraordinary abilities of its students but realising their further "profitability" for the Academy. Parrot was by no means an outstanding experimental scientist of his time; he loyally supported basic Enlightenment concepts and tended not only to obtain scientific knowledge, but also to apply it for the benefit of the society. Many essays of Parrot were devoted to the practical use of physics. After moving to St. Petersburg, Parrot focused on management, rather than research. Parrot first settled down to the upgrade of the Academy's Physics Room, and then he went about the foundation of its new Astronomical Observatory to the pattern of the one of the Dorpat University. Parrot's resignation from the Academy at the beginning of 1840 was actually forced by the sharp disagreement between Parrot and Uvarov on the issue of the convergence between the Dorpat educational district and the Russian ones.

Keywords: Georges Frédéric Parrot, history of the Imperial St. Petersburg Academy of Sciences, scientific knowledge, Sergey Uvarov

\footnotetext{
The reported study was funded by RFBR according to the research project No. 17-03-00212A
} 


\section{Parrot's initial steps in St. Petersburg}

On April 26, 1826, the emeritus professor of the Dorpat University Georges Frédéric Parrot (1767-1852), famous in the scientific world for his numerous writings and discoveries in physics, was unanimously approved as the ordinary academician of solid and fluid mechanics (Bienemann, 1902; Hempel, 1999; Langins, 2004; Andreev, 2006; Tohvri, 2011; Müürsepp, 2013). Devoted to the principles of the French Enlightenment, Parrot applied its ideas to arrange the University in Dorpat; he strictly observed the autonomy of the University and advanced science and technologies at the same time.

Parrot was elected at the very beginning of the reign of Nicholas I. The Emperor, who ascended the throne under the cannon fire at Senate Square in December 1825 , led Russia into the new epoch of its history. The imperial decree of July 13, 1826 proclaimed the completion of the trial of Decembrists. According to the decree, the furious spirit came not of "education but both of idle spirit and fatal luxury of semi-knowledge". Nicholas I declared his desire to favor "every thought of expanding the true education" (PSZ, 1826, pp. 773-774). His declaration was meant to encourage all members of the Academy of Sciences, especially its president Sergey Uvarov (1786-1855) (Whittaker, 1984).

It was at this time that the Academy made intent preparations for its centenary. Uvarov did his best to show the Academy in all its glory. The main building of the Academy was carefully arranged, and the great conference hall was tastefully decorated to hold a jubilee meeting (Fig. 1). Medalist Fyodor Tolstoy created a jubilee commemorative medal, which combined the names of three monarchs: Peter I, the founder of the Academy of Sciences; Alexander I, the organizer of the Academy's strong existence at the end of its first century; and Nicholas I, the Academy's hope for the new century. The visit of Nicholas I and the members of the imperial family to the Academy became the climax of the celebration (Sobranie aktov, 1827). In contrast to the public indifference to science, the jubilee was considered to be its advertising campaign indeed; it also widely promoted the activities of the Academy of Sciences.

The centenary celebration of the Academy became a turnaround in Uvarov's career, which had fallen in disgrace by that time. Having presented the Academy of Sciences as the original and oldest institution ordained by the supreme power, he could draw the Emperor's attention to himself and catch a chance to return 


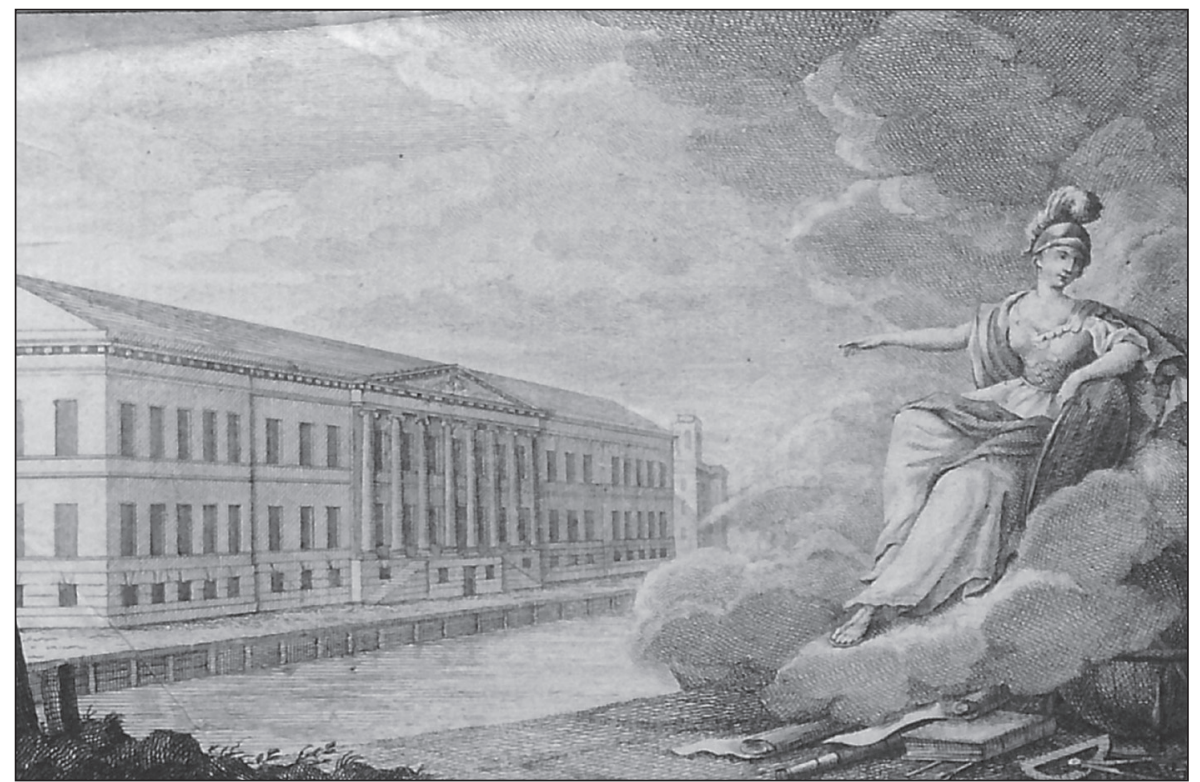

Figure 1.

The main building of the Imperial St. Petersburg Academy of Sciences (Nova Acta Academiae Scientiarum Imperialis Petropolitanae, 1787, vol. 1)

into mainstream politics. He was soon offered the position in the Ministry of Public Education which he headed over the years.

The Academy's scientists also counted on the Emperor's favor; they hoped to receive additional state appropriations to revitalize the institution. By that time, the real earnings of the academicians had decreased by a third, owing to inflation; the academicians themselves used to joke that they worked "for a sandwich". For example, the professor at Gymanasium illustre in Mitau, Magnus von Paucker, who by the way had been a student of Parrot's, refused to get elected the ordinary academician of astronomy. He justified his refusal on the basis that he earned up to 5,700 rubles, whereas the salary for an academician was but 2,200 rubles. The Academy's members would regret that for the reasons of very modest means it was impossible to invite worthy scientists, who felt much more comfortable even as teachers. Some academicians actually called for the temporary refusal to elect new members of the Academy.

It is not surprising that Uvarov was happy to "get" Parrot, a "personal friend" of Alexander I's and the first rector of the University of Dorpat (Bienemann, 1902; 
Andreev, 2006); it proved to be really beneficial for the Academy, especially on the eve of the jubilee celebration.

Of course Parrot could not help but worry about the financial part of the matter, which is why he tried to clear the conditions and terms of his entrance into the Academy in detail. He agreed, only on the condition that he retained his annual pension of 5,000 rubles that he received after leaving the University of Dorpat (SPbF ARAN, 1826, XIII). If he lost the pension, which was bigger than the double salary of an academician, he would never enter the Academy. Uvarov managed to obtain such a privilege for Parrot, although it was contrary to the Academy's Charter. In addition, Parrot desired to be confirmed that his wife would retain the pension after his death. However, it was decided to be rather inconvenient to ask the pension for Parrot's wife before his death, and indeed according to the Regulations (Charter) of the Academy only academicians' widows had the right to receive pension (RGIA, 1826).

Yet the academicians did understand Parrot's requests which lived up to their own expectations. In March 1826, they appealed to the President to recost their salaries with regard to the inflation and triple the rate of those (RGIA, 18261830, pp. 2-3). Though Uvarov considered their requests to be fair, he dared not ask too much, that is why he solicited but for doubling the regular funds (RGIA, 1826-1830, pp. 14-14v). In response, Nicholas I allowed Uvarov to draw up a new staff (budget) of the Academy of Sciences (RGIA, 1826-1830, p. 12).

At the Academy's public meeting, held at the end of 1827, Uvarov repeated "the word of the Emperor" to the academicians. He also informed scientists, in the newspapers, that the Academy was provided with money "to join the men that had distinguished themselves in science" (Rech'..., 1827). Yet Uvarov appeared to do it at the wrong time: the war against Turkey put off paying those salaries. The new staff was approved only on January 30, 1830; as a result, the general amount of funding increased twofold, in comparison with the Regulations of 1803 (PSZ, $1830 \mathrm{a} ; 1830 \mathrm{~b})$. The academician's salary went up to the one of the professor of Dorpat University and amounted to 5,000 rubles a year.

However, with the active assistance of Parrot, Uvarov had managed to recruit many eminent scientists of Dorpat, even before the new staff regulations came in force. For example, the zoologist Karl von Baer and the mineralogist Adolph Kupffer joined the Academy as ordinary academicians, the physicist Emil Lenz and the chemist Hermann Hess as adjuncts in 1828-1829. Later, also the zoologist Johann Friedrich Brandt and the astronomer Friedrich Georg Struve 
were elected. Not only did these scientists change the Academy of Sciences into a great scientific centre, but they also elevated it up to the standards of the foremost academies of the world.

A primary focus of Parrot was to improve the educational standards of Russia. Having prepared the draft of the Professors' Institute in Dorpat, Parrot made a valuable contribution to the Russian system of higher education. Uvarov was among those who supported this Parrot's plan (Rozhdestvenskiy, 1902, pp. 186-187). Three-year training at the Professors' Institute, where lectures were given in German, was so superior that it was taken as actual "purgatory" for the future Russian professors who went abroad to get some "scientific luster". During ten years (1828-1838), the Institute was a kind of a greenhouse where Russian scientists were "growing to maturity". The young men, sent to study at the Institute or University of Dorpat, were jokingly called "Professor-Embryonen" (i.e. professors in embryo or embryos of the professor) there (Pirogov, 1910, p. 448).

Uvarov considered it prestigious that the academicians should take part in the appraisal of the graduates of the Professors' Institute. For that reason, the Academy of Sciences was involved in selecting the future students of the Institute, along with assigning its graduates to universities. For instance, 24 graduates were appraised in the Academy of Sciences in summer 1828; 18 young scientists returned abroad in 1835 . Before going to their duty stations, every graduate gave a talk pro venia legendi at the Academy. It was Uvarov who prescribed them to lecture to the academicians. By that time, he had become the Minister of Public Education. The detailed report of those trials was presented in the Journal of the Ministry of Public Education, founded by Uvarov. The report said urbi et orbi that the new generation of Russian professors had appeared ( $O$ probnykh lektsiyakh, 1835). 


\section{Parrot's academic activity and upgrade of the Academy's Physics Room}

Parrot was by no means an outstanding experimental scientist of his time; he loyally supported the basic Enlightenment concepts and tended not to obtain scientific knowledge, but rather to apply it for the real benefit of society (Hempel, 1999). As an academician of physics, Parrot was also obliged to regularly inspect the lightning rods at the Okhta Powder Plant and elsewhere. When delivering the report about conditions of the plant in 1828, Parrot drew the academicians' attention to the fact that the Academy's buildings missed lightning rods. As a result, he was charged by the Conference to set the ones on those buildings. $\mathrm{He}$ also took part in many other events. For example, he reviewed the competing essays which were submitted at the Academy. It was Parrot who approved the research work of Hermann Heinrich Hess (1802-1850). As a result, the latter was elected to be an adjunct on October 29, 1828.

Parrot elaborated instructions for the expeditions of the members of the Academy. In 1829, the Academy of Sciences equipped the expedition to the Caucasus to study the natural resources in the surroundings of Elbrus. Parrot took part in drafting the program of physical observations for Adolph Kupffer and Emil Lenz (SPbF ARAN, 1829, pp. 3-7, 12-17). Parrot headed the commission which presented research tasks to the scientists who had been appointed to accompany the ecclesiastical mission in China in 1830-1832. Georg Fuss was assigned to geographic, magnetic, hypsometric definition, and Alexander von Bunge conducted studies in natural history. Parrot prepared for Fuss instructions for the physical observations (SPbF ARAN, 1839, pp. 28-29 v.). In 1836-1837, the Academy equipped an expedition to define the difference in the levels of the Caspian and Black seas. Parrot made a plan of barometric measurement for Georg Fuss, Alexei Sawitsch and Egor Sabler (Parrot, 1836, pp. 81-87, 8992) and undertook himself business trips to the Baltic region to pursue zoopalaeontological research at Lake Burtneck (Burtnieks) near Wolmar (Valmiera, Latvia) in 1832 and 1835 (Parrot, 1838a; 1838b).

Many essays of Parrot were devoted to the practical use of physics: among other things, he was occupied with improving the lightning rod; he also proposed protecting bank notes against counterfeiting by means of galvanoplastics.

In 1826, Parrot volunteered to adapt the alcoholometer of J. L. Gay-Lussac for the quality of Russian spirits and to make operating it easy as well. In Europe, 
the alcoholometer was a device of national importance; it was used to measure the amount of alcohol in liquids, which directly influenced their cost and tax rate as well. In 1826, the French physicist and chemist Joseph Louis Gay-Lussac presented Nicolas I with his ingenious alcoholometer to measure the alcoholic strength of solution, i.e. percentage of alcohol in the volume of solution at $15^{\circ} \mathrm{C}$. The alcoholometer had a 100-degree scale of "water" to "absolute alcohol". It came with special tables of solutions with different types of concentration calculated on the basis of values of specific weight of water and alcohol. In France, Gay-Lussac was generously rewarded for his invention that was adopted then by the French authorities. The alcoholometer of Gay-Lussac did not meet the Russian standards of measuring because of really different units of alcohol measurement. Nicolas I had an alcoholometer of Gay-Lussac ordered for the Ministry of Finance, which was interested in a useful tool for measuring the alcoholic strength of spirits in practice. From there, the alcoholometer was delivered to the Academy of Sciences for thorough examination. Parrot's research resulted in the development of the theory of hydrometry and a practical guide to it (Recueil..., 1828, pp. 21-22; SPbF ARAN, 1826b). The system proposed by Parrot was approved by the Academy's Conference, but he dropped his research and never completed his alcoholometer. Having visited Ye. F. Cancrin, the Minister of Finance, in fall 1829, Parrot lost all interest in the work. He did hope for the Minister's support and guarantee that his alcoholometer would actually come into use. That is why he was bitterly disappointed when the Minister told him that the state had no need for such expensive devices since the excise was abolished in 1827. Parrot decided that his further hydrometric research would never benefit either science or himself, and for that reason he withdrew from that work.

The Academy found in the person of Parrot a great manager of science. It was he who founded an exemplary physics laboratory and Astronomical Observatory at the Dorpat University. After moving to St. Petersburg, Parrot settled down to the upgrade of the Academy's Physics Room, although he was the academician of mathematics and consequently he was unable to do it. At that time the only Chair of Physics was held by Vasily Petrov (1761-1834); Petrov unfortunately was too old and sick to be able to create the laboratory (Eliseev, 1940). Describing the current conditions of the Physics Room, Parrot informed the Conference of the Academy that it missed even such essential pieces of physics equipment as thermometers, barometers, balances, etc. Parrot offered to outfit it with stateof-the-art tools and machines and also decided how to fill and arrange it (SPbF ARAN, 1826, XXX, pp. 11-11v). 
Petrov felt deeply offended by Parrot's report, which is why he presented his objections to the remarks of that "Mr. New Academician" (as he neglectfully called Parrot) to the Conference (SPbF ARAN, 1826, XXXII, pp. 7-8 v). Although the Conference agreed with Parrot's requests, it was against violating the rights of Petrov as the director of the Physics Room. To legalize Parrot's claims for the Physics Room and join him for managing it, the President suggested that the Conference should recognize Parrot as the academician of physics in excess of the staff. Yet, it was not officially approved by Alexander Shishkov, the Minister of Public Education. In his opinion, whether Parrot was elected to a position at the Chair of Physics, both of those of Applied Mathematics would be vacant. According to the Minister, if Petrov agreed to let Parrot manage the Physics Room, they could "exchange their subjects" (RGIA, 1826, pp. 42-42v). Yet, Petrov definitely withheld his consent to such an "exchange", even though he had been asked. As a result, Parrot was moved to the Department of Physics only in 1830, when the new staff regulations came into force; the regulations made provision for two positions of physicists and abolished the position of the academician of solid and fluid mechanics as well.

Parrot took charge of the Physics Room in June 1827 when the president demanded to move the physics tools and devices from the Kunstkammer into the main building of the Academy of Sciences. On June 15, 1827, the president ordered to have Petrov dismissed from managing the Room, but Petrov played for time and stubbornly refused to hand the keys over to the permanent secretary P. Fuss (SPbF ARAN, 1827, p. 3). Uvarov told the members of the Committee of the Academy's Board to open the Physics Room "with the aid of a locksmith" then. However prior to breaking in the Room, Petrov gave an official refusal to manage it at the Conference meeting on June 20, 1827. He handed the keys and control of the Physics Room over to Parrot (Eliseev, 1940, p. 182).

In 1828, Parrot was assigned the sum of 25,000 rubles to supplement the Physics Room with new pieces of equipment. Such a great amount of money made it possible to buy the instruments and devices necessary for various physics experiments. Spacious mahogany cabinets for the physics laboratory were made to Parrot's drawings. A century later, Academician Sergey Vavilov wrote: "Hardly had Parrot equipped the Room than the Physics Room became a true physics laboratory in its contemporary sense" (Vavilov, 1946, p. 23).

The renovated Physics Room proved invaluable for the experiments of Parrot and his successor Emil Lenz, which had assisted Parrot in the Physical Laboratory of Dorpat University. Parrot showed deep concern for his former student Heinrich 
Friedrich Emil Lenz (1804-1865): Under Parrot's advice, a young scientist, who had just graduated the university, was appointed as the physicist on the Russian sailing sloop "Predpriyatie" ('Enterprise'), led by Otto von Kotzebue around the world. During this expedition (1823-1826), Lenz carried out oceanographic research which favored his election in the adjunct of physics in 1828. Parrot was right to recommend Lenz for that position because at the Academy Lenz became the closest colleague of him. Parrot favored the young scientist and it was definitely the right decision: basic discoveries about electrodynamics are connected with the name of Lenz.

\section{Founding a new astronomical observatory}

After upgrading the Physics Room, Parrot went about founding a new astronomical observatory modelled after the one of the Dorpat University. That observatory, which thought to be one of the best in the Russian Empire, was founded in 1814, when Parrot was Rector of the University.

Because of the rising scientific requirements, the Academy of Sciences had long since felt the need for a new observatory. In the early 19th century, the Academy's observatory was situated in the Kunstkammer Tower on Vasilyevsky Island, where heavy traffic caused instruments to vibrate, and numerous chimneys around the observatory emitted smoke so thick that it really obscured the horizon. The observatory was planned to be moved away from the capital as far back as in the 18th century; yet those plans remained unfulfilled for a number of reasons. After approving the new staff regulations of the Academy of Sciences in 1830, the issue of the founding of a new astronomical observatory was readdressed (Abalakin, 1994). In summer 1830, the Conference authorized Parrot to find a place suitable for the observatory and also to draw up its draft, estimate, and staff. Parrot could justify the academicians' hope, and soon the dream of a new advanced observatory came true. The idea was backed by Count Alexander Kushelyov-Bezborodko (1800-1855), the enlightened patron of the arts and science. Parrot had showed warm hospitality to him in Dorpat some years before. Kushelyov-Bezborodko offered the area of his private land in the district Vyborgskaya Storona ('Vyborg side') to build the observatory (on November 1, 1830). To show its gratitude, the Academy of Sciences elected the Count as its honorary member (on December 8, 1830). 
Having drawn up the draft of the future observatory, Parrot corrected it according to the remarks of Friedrich Georg Wilhelm Struve (1793-1864), the then director of the Dorpat Observatory. Parrot was formerly the first who saw the exceptional abilities for astronomy in young Struve. It was Parrot who not only persuaded Struve to abandon his career in philology, which he had planned to make, but also encouraged and helped him through studying exact sciences. In 1819, Struve became the director of the Dorpat Observatory, and in 1826, during the Academy's 100th anniversary celebration the 33-year-old luminary of applied astronomy was honored by being elected as honorary member of the Academy of Sciences.

At the end of 1830, Struve came to Petersburg to report the results of his business trip abroad to the Emperor. During an audience with Nicholas I, Struve not only told the monarch about the European observatories he had visited but, according to him, also gave "the frankest and truest report" on the poor conditions of the Academy's observatory (Struve, 1845, pp. 24-25). In January 1832, Struve was elected ordinary academician with the right to live in Dorpat until the Academy had its own observatory, which was in itself evidence of the firm resolution of the authorities to build the astronomical observatory.

The issue was finally settled in 1833, when the president of the Academy of Sciences Sergey Uvarov was appointed the Minister of Public Education. He presented "The Academy's project on Building the New Astronomical Observatory" to the Emperor. The Project was supplemented with Parrot's draft, which was "suited" to the one of the Dorpat Observatory, different only in details (Figs. 2-3).

On October 28, 1833, Nicholas I commanded that "the instruments be bought and the Ministry of Finance be requested to assign 100 thousand rubles for starting the construction at the most favorable place" (Abalakin, 1994, p. 36). Uvarov constituted the commission of academicians-Struve, Vishnevsky, Parrot, and Fuss - to work out the details of the project. Admiral and honorary member of the Academy of Sciences Aleksey Greig (1775-1845), the expert in applied astronomy and founder of the observatory in Nikolayev (1827), headed the Commission. It prepared the draft Charter and Staff of the Observatory and chose the place for the site at the top of Pulkovo Hill, $19 \mathrm{~km}$ south of St. Petersburg. The Emperor appointed Struve as its future director. It took Struve several years to buy up-to-date instruments for the observatory. 


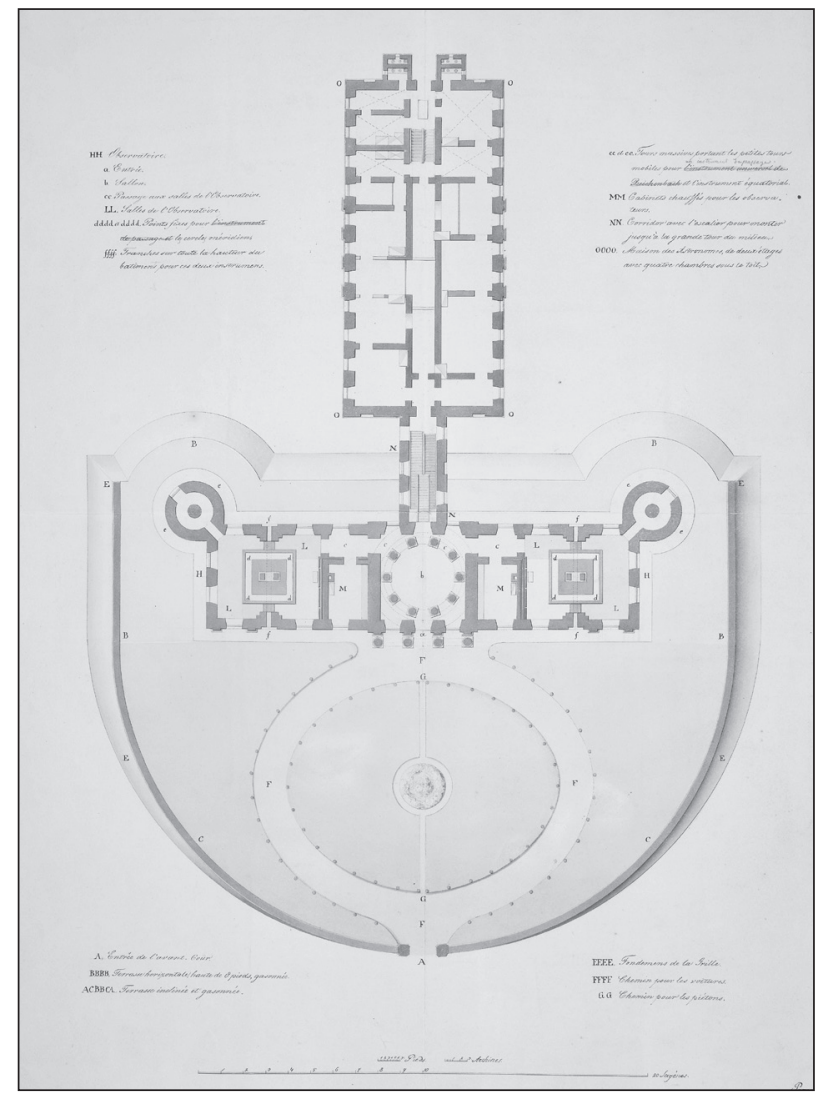

Figure 2.

G. F. Parrot's draft of the Astronomical Observatory, 1830. (From the collections of SPbB ARAS)

To move on to the question of the construction budget, on December 8, 1833, the Commission reviewed the drawings of the plans and the facade of the building projected by Parrot. While doing justice to this fine work, the Commission rejected it because it did not respond to the views that served as the basis for the new project of the central observatory in the Russian Empire. The Commission decided to create a new plan for the observatory on a broader basis, and proposed to entrust the young architects of the Academy of Arts, Alexander Brullov and Konstantin Thon, with the task of drawing up the architectural designs of the observatory independently from each other (SPbF ARAN, 1833, p. 6v).

On December 20, 1833, Uvarov presented the draft Charter and Staff of the Observatory for the Emperor's judgment. Nicholas I sent the papers back with the following remark: "Right. Since the first draft of the building was drawn up by Mr. Parrot, you should offer him to do it for this program, not to offend him, and then choose the best of those three" (RGIA, 1833-1834, pp. 53-53v, 59). 


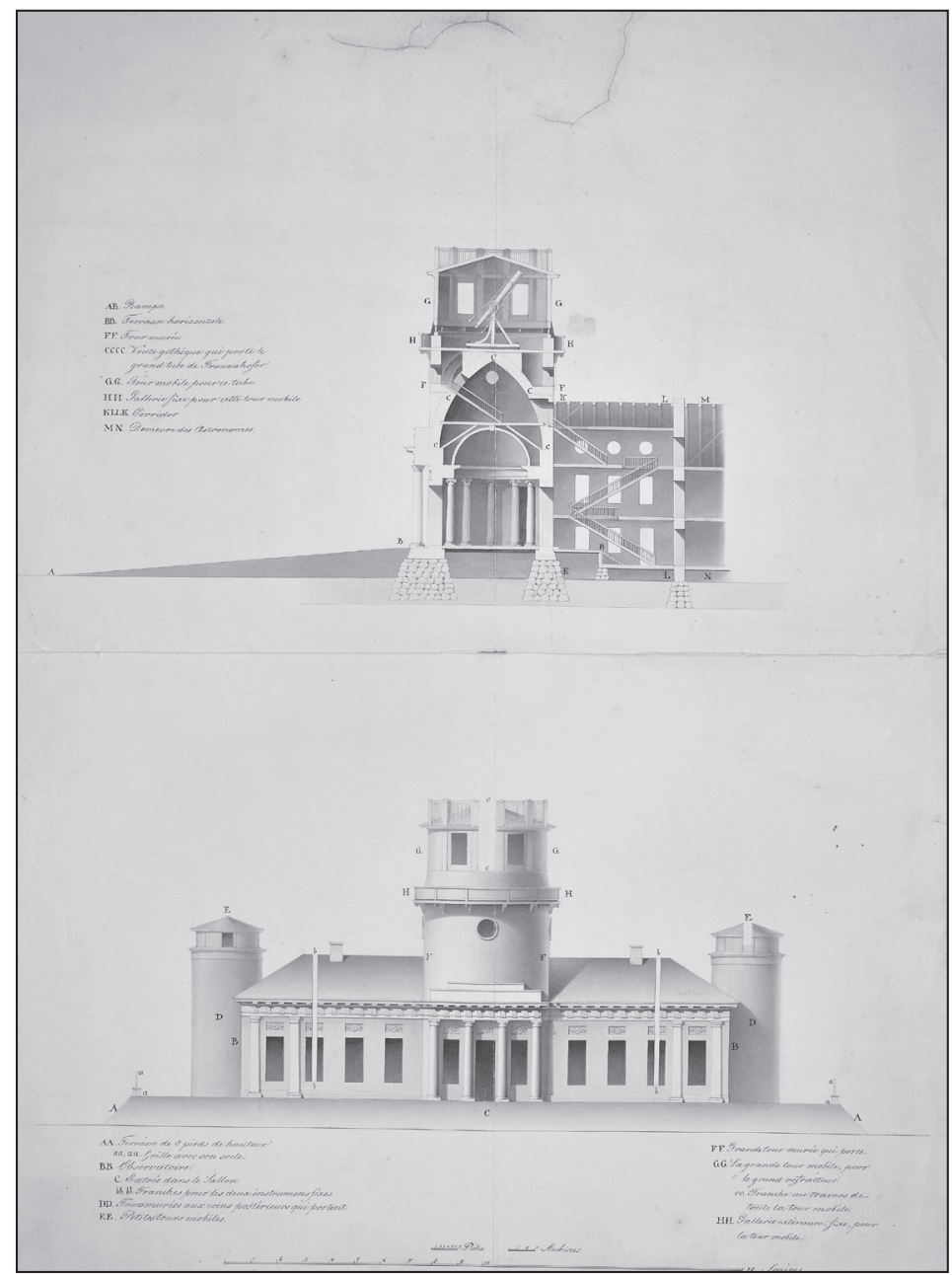

Figure 3. G. F. Parrot's draft of the astronomical observatory, 1830.

(From the collections of SPbB ARAS)

Parrot decided to withdraw from the contest. However, he drafted letters to the Emperor, with evidence of his right to be the designer of the observatory, and prepared a new draft of the observatory building, with due regard to its location on Pulkovo Hill, designed the rotary domes and constructed a machine for bricks (Figs. 4-8). He mocked the "young" architects and ridiculed the inept administrative actions of Minister Uvarov (LNA-LVVA, 1834, pp. 52-56). 


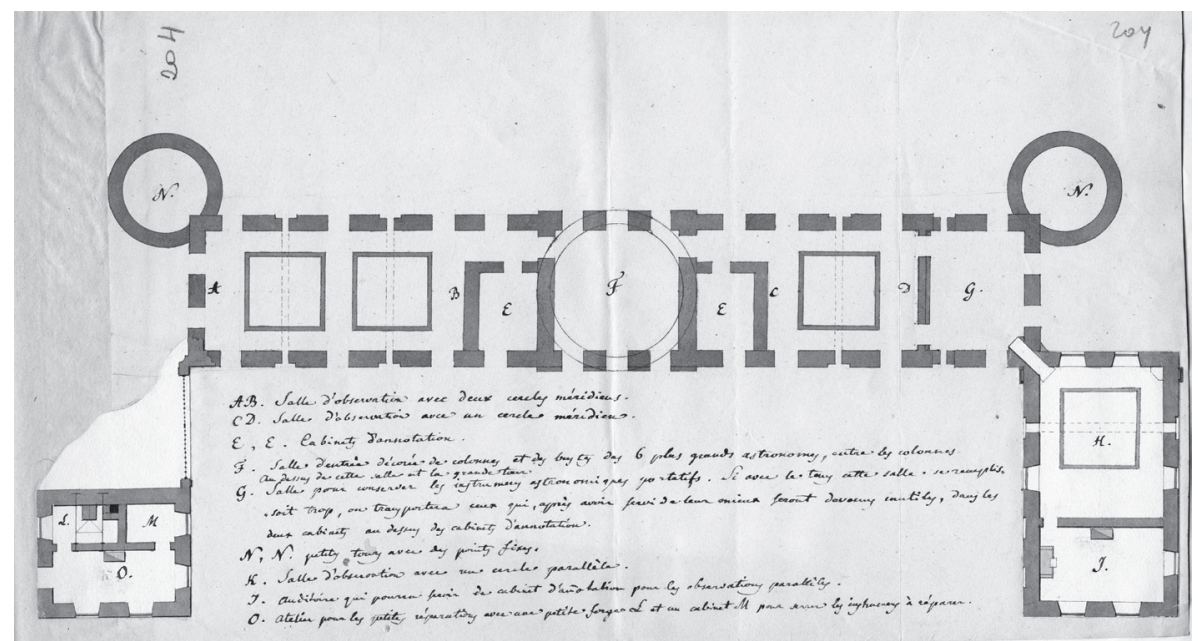

Figure 4. G. F. Parrot's draft of the astronomical observatory, 1834.

(From the collections of LNA-LVVA)

Despite personal offense, Parrot gave the "young" architects his drawings and acted as an expert in the competition.

On February 24, 1834, Alexander Brullov and Konstantin Thon presented to the Commission their sketches and gave oral explanations. Thon drew the draft of the building like a medieval castle, while Brullov did it in an up-to-date style. Since Brullov's project suited the research purposes much better, it was unanimously chosen by the Commission and approved by Nicholas I in April 1834 .

On June 21, 1835, the observatory was solemnly founded. The construction went well; as a result, it was finished in 1839. The Pulkovo Observatory, which later became famous all over scientific world as Imperialis Primaria Rossiae Specula Academica, was inaugurated on August 7, 1839 in the presence of almost all Russian astronomers. Having become a historic event in the life of every educated Russian, the founding of the Pulkovo Astronomical Observatory heightened the scientific value of the Academy of Sciences. Having combined "the science of observation" with "the art of observation", Struve could for a long time pattern the research work of the observatory. Thanks to his achievements in basic astronomy, the Pulkovo Observatory attained renown as the astronomical capital of the world. 
Figure 5.

Parrots Entwurf einer Drehkuppel (Parrot's draft of a rotary dome), 1834.

(From the collections of SPbB ARAS)

Figure 6. Parrots Entwurf einer Drehkuppel (Parrot's draft of a rotary dome). Details, 1834. (From the collections of SPbB ARAS)
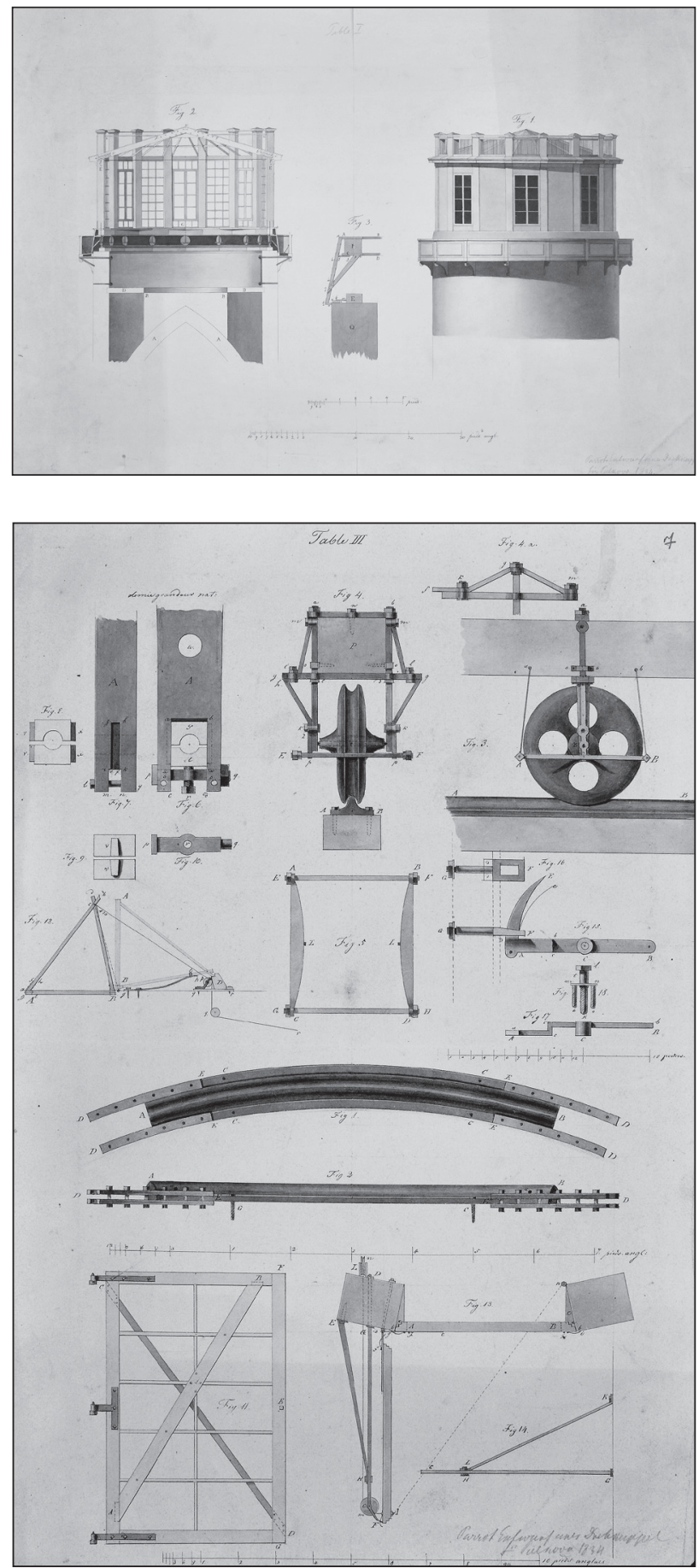


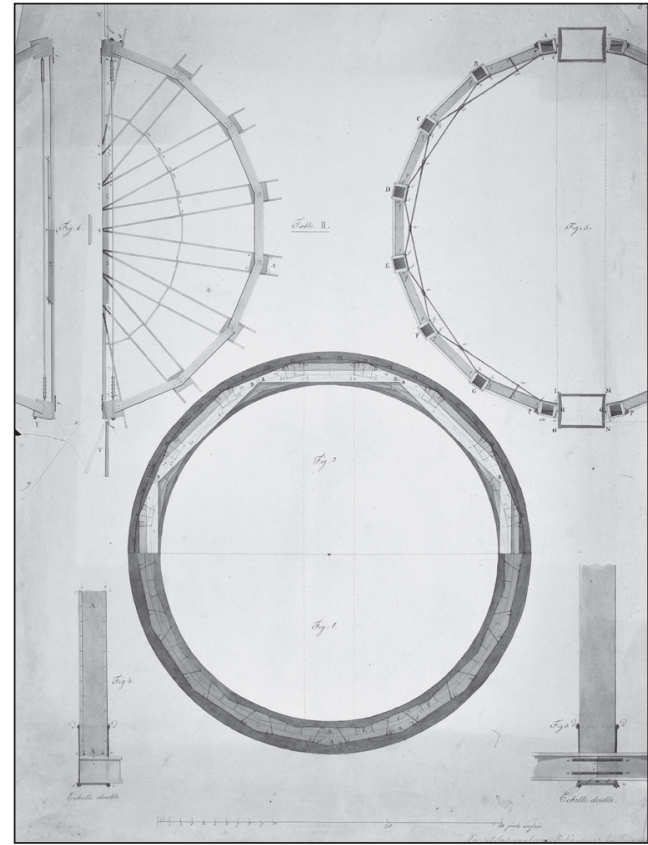

Figure 7. Parrots Entwurf einer Drehkuppel (Parrot's draft of a rotary dome). Details, 1834.

(From the collections of SPbB ARAS)

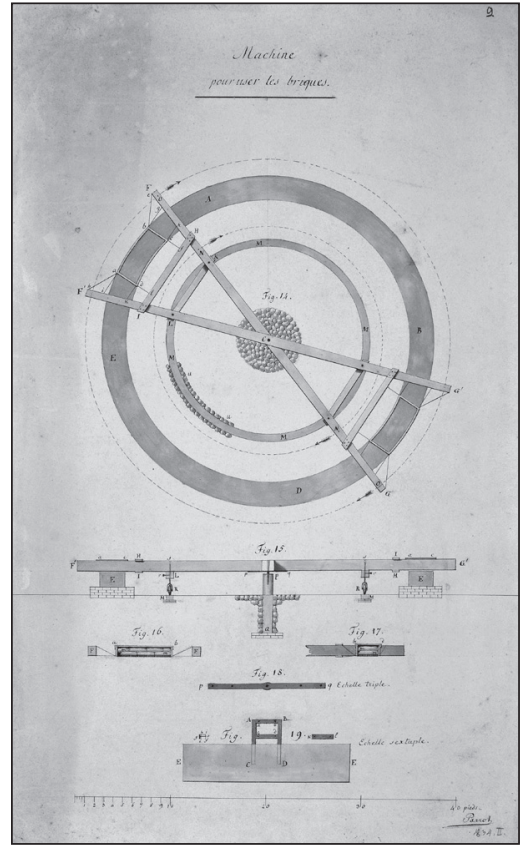

Figure 8. Parrot's draft 'Machine pour les briques' (Machine for bricks), 1834.

(From the collections of SPbB ARAS) 


\section{Resignation}

Numerous duties overwhelmed Parrot, which is why he had to resign at the beginning of 1840 . The resignation was actually forced by a sharp disagreement between Parrot and Uvarov, who had become the "lord and master" of education by that time, concerning the issue of the prospective Russification of the Ostsee (Baltic) governorates. In 1839, Parrot felt deeply disturbed when he read in newspapers about the idea of the convergence between the Dorpat educational district and the Russian ones, which had been long nurtured by Uvarov. That convergence meant the starting of teaching and record-keeping in Russian in the Ostsee governorates. Uvarov proposed his plan for the Emperor to consider it in 1836 and 1838; those reports were not intended for other ministers, especially not for the public. Nevertheless, Uvarov's "secret" reports filtered into the press, which is why Parrot could read the Minister's report of May 7, 1838 in the German newspaper Allgemeine Zeitung of February 21, 1939 (Buchholtz, 1883, pp. 23-25). The remark "Right" by Nicholas I in the margins of the paper resounded with pain in Parrot's soul and forced him to address a lengthy letter to the Emperor. Both the contents and the poisonous tone of the letter proved undoubtedly that Uvarov and Parrot had broken off relations. "The ungrateful person," as Parrot called Uvarov, "has forgot that he owes his own educational background to one of the German universities" "Der Undankbare vergisst, dass er seine eigene Bildung einer deutschen Hochschule verdankt"; Bienemann, 1895, p. 231). After having resigned, Parrot spoke of Uvarov in much worse terms; for example, he even called him "a despicable Minister" ("ein verachtet Minister") in his letter to the Emperor of June 1 (13), 1843 (Bienemann, 1895, p. 232).

Outwardly, the resignation was arranged in a quite proper manner: Parrot pled his advanced age and the illness caused by it. His resignation letter was supplemented with the lines from Horace: Quid valeant humeri, quid ferre recusent ('Consider deeply what your shoulders can and cannot bear') (SPbF ARAN, 1840, I, p. 23) (Fig. 9). Having resigned on November 29, 1840, Parrot was granted the lavish pension that Uvarov had got for him. Once having settled the matters, Parrot made haste to see his hopelessly ill son, who died in January 1841. At the end of 1840, Parrot was elected an honorary member of the Academy of Sciences.

Parrot gave nearly 15 years of his life for the Academy of Sciences, and we should appreciate his wide and varied academic activities, which opened a new era in its history. As a spokesman of the Enlightenment ideology and a person active in establishing the new area of scientific research in St. Petersburg, Parrot focused 
on the founding of new academic institutions following the model of those in Dorpat. Simultaneously he was a kind of Uvarov's agent at the University of Dorpat, a person not only capable of estimating the extraordinary abilities of its students but also of realizing their further "profitability" for the Academy. Unfortunately, Uvarov's gross violation of liberal values and ideological tricks turned Parrot's plans into an Icarian flight and led him to resignation.

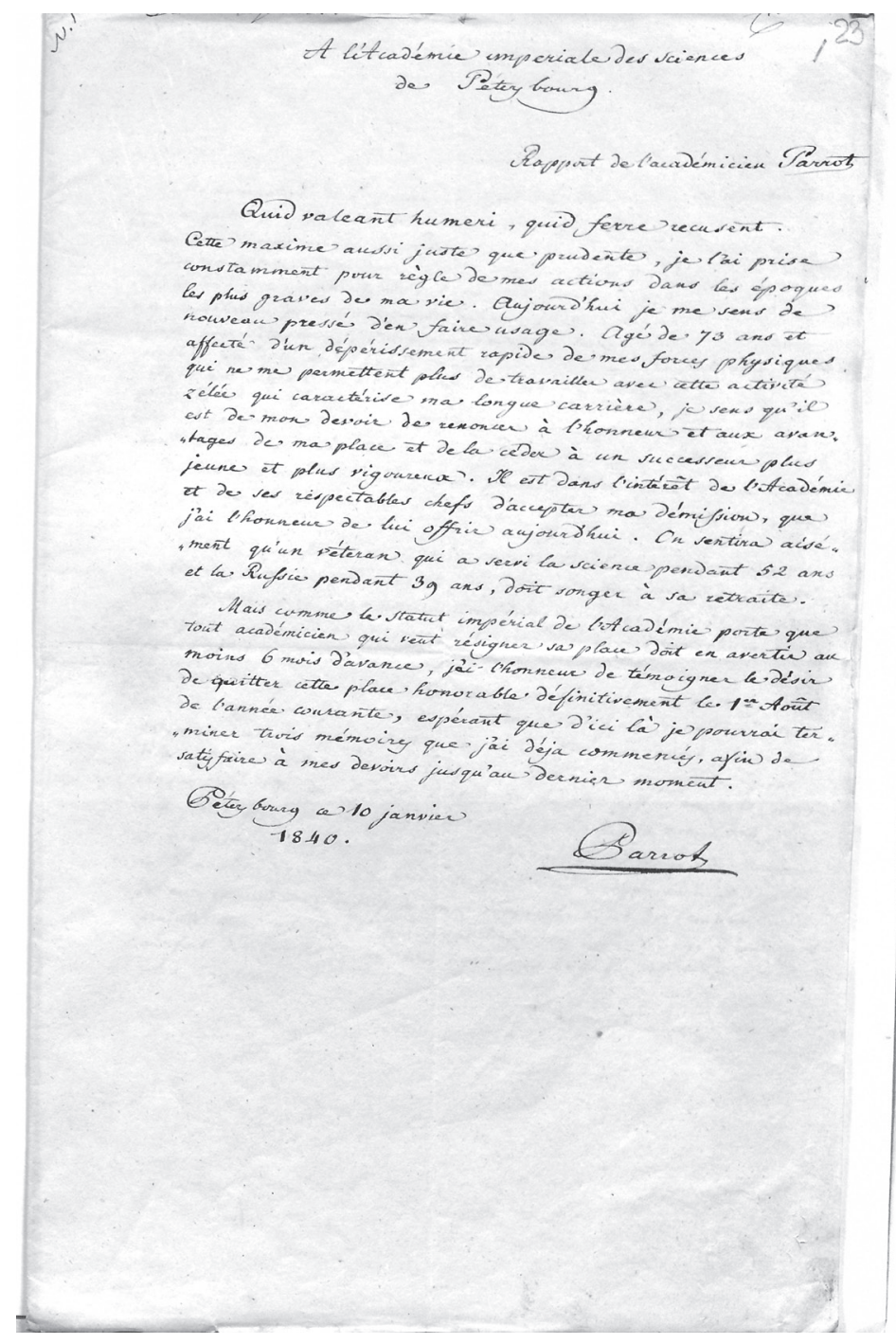

Figure 9. G. F. Parrot's resignation letter, 1840.

(From the collections of SPbB ARAS) 


\section{Acknowledgments}

The author wishes to thank Epi Tohvri, who generously offered advice to the author, and Olga Kirikova for assistance in translating the article.

\section{References}

Abalakin, V. K., ed. (1994), Glavnaya astronomicheskaya observatoriya v Pulkove, 1839-1917 gg.: Sbornik dokumentov [Pulkovo' Primary Astronomical Observatory in 1839-1917: Collection of Documents], Sankt-Peterburg: Nauka.

Andreev, A. (2006), 'Imperator Aleksandr I i professor G. F. Parrot: k istorii vozniknoveniya "Universitetskoi avtonomii" v Rossii' [The Emperor Alexander I and Professor G. F. Parrot: the history of "University autonomy" in Russia], Otechestvennaia Istoriya, Moskva: Rossiiskaya Akademia Nauk, vol. 6, pp. 19-30.

Bienemann, F. G. (1895), 'Ein freiheitskämpfer unter Kaiser Nikolaus I,' Deutsche Revue über das gesamte nationale Leben der Gegenwart, vol. 20, no. 1, pp. 224-235.

Bienemann, F. G. (1902), Der Dorpater Professor Georg Friedrich Parrot und Kaiser Alexander I: Zum Säkulargedächtnis der alma mater Dorpatensis, Reval: Verlag von Franz Kluge.

Buchholtz, A. (1883), Fünfzig Jahre Russischer Verwaltung in den Baltischen Provinzen, Leipzig: Duncker \& Humblot.

Eliseev, A. A. (1940), 'V.V. Petrov—organizator fizicheskikh kabinetov v Rossii' [V. V. Petrov-founder of Physics Rooms in Russia], in S. Vavilov (ed.) Akademik V. V. Petrov: 1761-1834: K istorii fiziki i khimii v Rossii v nachale XIX v.: Sbornik statei i materialov, Moskva; Leningrad: Akademia Nauk SSSR.

Hempel, P. (1999), Deutschsprachige Physiker im alten St. Petersburg: Georg Parrot, Emil Lenz und Moritz Jacobi im Kontext von Wissenschaft und Politik, Munchen: Oldenbourg.

LNA-LVVA (1834), Chernoviki pisem P. Parrota imperatoru Nikolayu [Drafts of the letters of Parrot to Emperor Nicholas], f7350, op 1. d 11, Latvian National Archives, Latvian State Historical Archives.

Müürsepp, P. (2013), 'Georges Frédéric Parrot and the “New” Enlightenment,' Acta Baltica Historiae et Philosophiae Scientiarum, vol. 1, no. 2 (Autumn 2013), pp. 15-25. https://doi.org/10.11590/abhps.2013.2.02

O probnykh lektsiyakh (1835) 'O probnykh lektsiyakh universitetskikh vospitannikov, nedavno vozvrativshikhsya iz-za granitsy' [Regarding trial lectures of the students which have recently returned from abroad], Zhurnal Ministerstva narodnogo prosveshbeniya, no. 9, pp. 507-533. 
Parrot, G. F. (1837), 'Mémoire sur l'expédition pour déterminer le niveau de la mer Caspienne. Lu le 8 juillet 1836. Extrait,' in Bulletin scientifique publié par l'Académie impériale des sciences de Saint-Pétersbourg, vol. 1, pp. 81-87, 89-92.

Parrot, G. F. (1838a), 'Essai sur les ossements fossils des bords du lac de Burtneck en Livonie. Lu le 27 septembre 1833', in Mémoires de l'Académie impériale des sciences de St.-Pétersbourg, sér. 6, Seconde partie, Sciences naturelles, vol. 2, pp. 1-94.

Parrot, G. F. (1838b), 'Rapport sur son second voyage au lac de Burtneck en 1835. Lu le 18 septembre 1836', in Mémoires de l'Académie impériale des sciences de St.-Pétersbourg, sér. 6, Premiére partie, Sciences mathématiques et physiques, vol. 1, pp. $\mathrm{xxv}-\mathrm{xxxv}$.

Pirogov, N. I. (1910), 'Voprosy zhizni. Dnevnik starogo vracha' [Matters of life. Diary of an old doctor], in Pirogov, N. I.: Sochineniya, vol. 2, Kiev: Izdatel'stvo Pirogovskogo tovarishhestva.

Recueil... (1828), Recueil des actes de la séance publique de l'Académie Impériale des Sciences de St.-Pétersbourg tenue le 29 Décembre 1828, Sankt-Peterburg: Tipografiya Imp. Akademii Nauk.

PSZ (1826), 'Manifest. O sovershenii prigovora nad gosudarstvennymi prestupnikami' [Manifesto. On execution of the sentence over state criminals], Polnoe sobranie zakonov Rossiiskoi imperii. Sobranie vtoroe, 1830, vol. 1 (December 12, 1825-1826), no. 465, Sankt-Peterburg: Tipografiia II Otdeleniia Sobstvennoi Ego Imperatorskogo Velichestva Kantselyarii, pp. 772-774.

PSZ (1830a), 'Shtat Imperatorskoi Akademii nauk,' in Polnoe sobranie zakonov Rossiiskoi imperii. Sobranie vtoroe, 1830, vol. 5 (1830), Shtaty i tabeli, Sankt-Peterburg: Tipografiya II Otdeleniya Sobstvennoi Ego imperatorskogo Velichestva Kantselyarii, p 7.

PSZ (1830b), 'Vysochayshe utverzhdennye dopolnitel'nye punkty k Reglamentu Imperatorskoi Akademii nauk' [Imperially approved additions to the Charter of the Imperial Academy of Sciences], in Polnoe sobranie zakonov Rossiiskoi imperii. Sobranie vtoroe, 1830, vol. 5 (1830), no. 3453, Sankt-Peterburg: Tipografiya II Otdeleniya Sobstvennoi Ego Imperatorskogo Velichestva Kantselyarii, pp. 103-104.

Rech'... (1827), Rech' g. prezidenta Imperatorskoi Akademii nauk, proiznesennaya $v$ publichnom sobranii Akademii 29 dekabrya 1827 goda [Speech of the President of the Imperial Academy of Sciences delivered in a Public Assembly of the Academy on December 29 1827], Pribavlenie k Sanktpeterburgskim vedomostyam, 3 Jan 1828, no. 1, pp. 1-4.

RGIA (1826), Po predstavleniyu prezidenta Akademii nauk ob utverzhdenii zasluzhennogo professora Derptskogo universiteta Parrota v zvanii ordinarnogo akademika [On the recommendation of the President of the Academy of Sciences on the approval of the honorary professor of the University of Dorpat Parrot in the rank of ordinary academician], f 733, op 12, d 309, pp. 23-25 v., Russian State Historical Archive, St. Petersburg. 
RGIA (1826-1830), Po predstavleniyu prezidenta Akademii nauk ob iskhodataistvovanii preobrazovaniya shtata Akademii, ob utverzhdenii shtata i dopolnitel'nykh punktov [On the proposal of the President of the Academy of Sciences about the ongoing change of the staff of the Academy, on the approval of the state and additional points], f 733, op 12, d 307, Russian State Historical Archive, St. Petersburg.

RGIA (1833-1834), O proekte i smete na sooruzhenie v Peterburge Glavnoi astronomicheskoi observatorii, a takzhe o rabotakh po ee postroike [About the project and estimate for the construction of the Main Astronomical Observatory in St. Petersburg, as well as about the works on its construction], f 733, op 12, d 530, Russian State Historical Archive, St. Petersburg.

Rozhdestvenskiy, S. V. (1902), Istoricheskii obzor deyatel'nosti Ministerstva narodnogo prosveshheniya, 1802-1902 [Historical overview of the main activities of the Ministry of Public Education, 1802-1902], Sankt-Peterburg: Gosudarstvennaya tipografiya.

Sobranie aktov (1827), 'Sobranie aktov torzhestvennogo zasedaniya Imperatorskoi SanktPeterburgskoi Akademii nauk, byvshego po sluchayu prazdnovaniya stoletiya ee sushchestvovaniya 29 dekabrya 1826 goda' [Collection of the Acts of the centenary celebration of the Imperial St. Petersburg Academy of Sciences, December 29, 1826], Sankt-Peterburg: Tipografiya Imp. Akademii nauk.

SPbF ARAN (1826, XIII assembly), Protokol'nye bumagi, f 1, op 2-1826, d 13 (XIII assembly, April, 25 1826, $\$ 134-145)$, pp. 26-26v., St. Petersburg Branch of the Archive of the Russian Academy of Sciences.

SPbF ARAN (1826, XXX), Protokol'nye bumagi, f 1, op 2-1826, d 30 (XXX assembly, October, 18 1826, $\$ 330-341)$, St. Petersburg Branch of the Archive of the Russian Academy of Sciences.

SPbF ARAN (1826, XXXII), Protokol'nye bumagi, f 1, op 2-1826, d 32 (XXXII assembly, November, 1 1826, $\$ 361-374)$, St. Petersburg Branch of the Archive of the Russian Academy of Sciences.

SPbF ARAN (1826a), Chernoviki i kopii protokolov Konferentsii Akademii nauk, f 1, op 1a, d 37, St. Petersburg Branch of the Archive of the Russian Academy of Sciences.

SPbF ARAN (1826b), O rassmotrenii spirtomerov, izobretennykh Gay-Lussacom, Lamberti and Kormilev, f 2, op 1-1826, d 1, St. Petersburg Branch of the Archive of the Russian Academy of Sciences.

SPbF ARAN (1827), Perepiska s Konferentsiei i nepremennym sekretarem Akademii nauk o peredache dela okhrany Fizicheskogo kabineta Akademii nauk akademiku Petrovu, f 5, op 1-1827, d 250, St. Petersburg Branch of the Archive of the Russian Academy of Sciences, St. Petersburg.

SPbF ARAN (1829), Sentiments des Académiciens Trinius, Parrot et Kupffer, concernant un voyage scientifique dans les contrées d'Elbrous, f 2, op 1-1829, d 4, pp. 3-7, 12-17, St. Petersburg Branch of the Archive of the Russian Academy of Sciences.

SPbF ARAN (1833), Zhurnal zasedaniy Komissii po sooruzheniyu Glavnoi observatorii $v$ Pulkovo, f 703, op 1-do 1917, d 5, St. Petersburg Branch of the Archive of the 
Russian Academy of Sciences.

SPbF ARAN (1839), Parrot G. F. Instruktion für die Begleiter der Russischen Mission nach China in Bezug auf das physikalische Programm, f 2, op. 1-1839, d 12, pp. 28-29v.

SPbF ARAN (1840, I), Protokol'nye bumagi, f 1, op 2-1840, d 1 (I Assembly, January, 10 1840), St. Petersburg Branch of the Archive of the Russian Academy of Sciences, St. Petersburg.

Struve, W. (1845), Description de l'observatoire central de Poulkova, Saint-Pétersbourg: Imprimerie de l'Academie imperiale des sciences.

Tohvri, E. (2011), 'Some new aspects of Georges Frédéric Parrot's visions about the institutional and architectural establishment of the University of Tartu in the early 19th century,' Baltic Journal of European Studies, vol. 1, no. 1(9), pp. 354-362.

Vavilov, S. I. (1946), 'Fizicheskiy kabinet - Fizicheskaya laboratoriya - Fizicheskiy institut Akademii nauk SSSR za 220 let' [Physics room - Physical laboratory - Physical Institute of the USSR Academy of Sciences in 220 years], Uspekhi fizicheskikh nauk, vol. 28, no 1.

Whittaker, C. H. (1984), The Origins of Modern Russian Education: An Intellectual Biography of Count Sergei Uvarov, 1786-1855, DeKalb, IL: Northern Illinois University Press.

Dr. Ekaterina Basargina earned her PhD and HD in History from Saint Petersburg Institute of history of Russian Academy of Sciences. She is a senior researcher at the St. Petersburg Branch of the Archive of the Russian Academy of Sciences. Her research focuses mainly on the history of the Russian Academy of Sciences. 